\title{
A Spatio-Temporal Changes in Cropping Pattern and Cropping Intensity in Agriculture to Get a Business Profit in Jammu and Kashmir
}

\author{
Javaid Ahmad Andrabi \\ Department of Geography, Govt. Degree College pampore, Jammu and Kashmir, India \\ andrabijavaidahmad@yahoo.com
}

\begin{abstract}
In the present paper an attempt has been made to analyze spatio-temporal changes in cropping pattern and cropping intensity in agriculture of Jammu and Kashmir. Data were obtained from Statistical Abstract of Jammu and Kashmir. Copping pattern and cropping intensity have been presented in the percentage forms. Results of the study reveal that cropping pattern is much diverse with high level of cropping intensity in agriculture of the state. It has been found that maize is still most cultivated crop in the state, covering an area of $27.4 \%$ to total cropped area during 2010-11. Wheat has been found second most cultivated crop with increasing trend of area. The area under rice and pulses crop has decreased rapidly over the period. Cropping intensity has also continuously increased from 119.70\% in 1965-66 to $155.79 \%$ in 2010-11. The highest cropping intensity has been recorded in samba (212.63\%) whereas lowest registered in Kupwara (100\%) district of the state.
\end{abstract}

Keywords: cropping pattern; cropping intensity; net sown area; gross cropped area.

\section{Introduction}

Agriculture plays a very important role for development of economy of Jammu and kashmir State. About $70 \%$ of the population in the State gets livelihood directly or indirectly fromthe Agriculture and allied Sectors. Jammu Kashmir extends between $32^{\circ} 17^{\prime} \mathrm{N}$ to $37^{\circ} 6^{\prime} \mathrm{N}$ latitude and $73^{\circ} 26^{\prime}$ to $80^{\circ} 30^{\prime}$ longitudeand is divided in to three agro climatic zone namely Jammu (subtropical zone), Kashmir(temperate zone) and Ladakh (cold arid zone ) having their distinct geo - climatic conditions which largely determines the cropping pattern and productivity of crops. Paddy is the dominant crop ofKashmir zone, followed by maize, oilseeds, pulses, fruits and vegetables, fodder and wheat. In of case Jammu region, wheat is the main crop followed by maize, paddy, pulses, oilseeds, fodder, fruits and vegetables and other crops while in Ladakh zone, barley is the chiefcereal crop followed by wheat and pulses.

The area under rice, maize and wheat crops together account for about $84.00 \%$ of total cropped area under food crops andproduce around $97.9 \%$ of total food grains. Cropping pattern is the percentage share of an area under different crops in a particular region during a particular agricultural year. Changing cropping pattern means the fluctuation and variations that occurred in these percentages with time. A change or shift in the cropping pattern implies a change in the proportion of area under different crops which depends to a large extent on the Geographical factors of the region. Moreover, the development of marketing infrastructure and the demand 
pattern of the people are also factor which affect cropping pattern (Hussain, 1979).Cropping Pattern is however, a dynamic concept as it changes over space and time. It is largely determined by climate, soil, availability of irrigation facilities, level of energy use and the socio-economic factors of aof a region. Cropping Intensity refers to raising of a number of crops in a specific agricultural field during an agricultural year. It is the ratio between net sown areas (NSA) to gross cropped area (GRA). Cropping intensity is closely related to irrigation facilities, consumption of fertilizers, crop combination and rotation, mixed cropping and relay cropping etc. Thus high cropping intensity means high level of agricultural development.

\section{Materials and Methods}

The Present study is primarily based on secondary data obtained from various issues of Digest of Statistics and other publications of the Directorate of Economics andStatistics, Government of Jammu and Kashmir, for the period 1965-66 to 2010-11. Cropping pattern shows the proportional area under various crops to total cropped area in the study area. Proportional area of various crops has been calculated with the help of total cropped area. Cropping intensity has been calculated by the ratio of net sown area to gross cropped area and multiplied by 100 . Gross cropped area is the addition of net sown area and area sown more than once. Net sown area refers to total area sown with crops and orchards counting area sown more than once in the same year only once (Agricultural Census, 2011). Formula of Cropping intensity express as:

\section{Gross Cropped Area}

Cropping Intensity $\longrightarrow 100$

Net Area Sown

\section{Discussion}

Cultivation of crops is the dominant occupation of Jammu and Kashmir state and is the leading economical activityfor the development of the state. However the total cropped area has increased from 745 thousand hectares in 1955-56 to 1139.81 thousand hectares in 2010-11 (Statistical Abstract of Jammu and Kashmir, 2012). Maize crop has always covered the largest area of total cropped area in the state and has recorded a decreased from $31.55 \%$ to $27.04 \%$ during 1965-66 to 2010-11 respectively (Table, 1.1). The area under wheat crop has continually increased from 19.05 per cent in 1965-66 to 25.52 per cent of the total cropped area in 2010-11. The area under paddy and other cereals and millets crop has declined from 26.02 per cent to 22.93 per cent and 5.76 per cent to 3.02 per cent respectively of total cropped area during same period.. The area underpulses (gram, mash, moong and massar) has also rapidly decreased from 5.80 per centto 2.54 per cent of the total cropped area between same periods. The area under 
oilseeds including mustard, rape seeds, linseeds, sasamum and groundnut has increased from 4.50 per cent to 5.66 per cent of the total cropped area between same periods. The area under fruits and vegetables and other non food crops has increased over the period whereas area under fodder crops has decreased in the state. There has not been found large changes in the area of other crops including vegetables, fruits and fodder crops in the state.

Table 1.1: Temporal Changes in Cropping Pattern in Jammu and Kashmir (1965-66 to 2010-11)

\begin{tabular}{|c|c|c|c|c|c|c|}
\hline crops & $1965-66$ & $1974-75$ & $1980-81$ & $1990-91$ & $2000-01$ & 2010-11 \\
\hline RICE & 26.31 & 26.31 & 27.19 & 25.78 & 21.93 & 22.93 \\
\hline Maize & 29.51 & 29.51 & 28.27 & 27.65 & 29.61 & 27.04 \\
\hline wheat & 21.25 & 21.25 & 20.73 & 22.98 & 25.19 & 25.52 \\
\hline $\begin{array}{l}\text { other cereals and } \\
\text { millets }\end{array}$ & 5.76 & 5.76 & 4.71 & 3.54 & 3.33 & 3.02 \\
\hline pulses & 5.80 & 5.80 & 4.99 & 3.87 & 2.46 & 2.54 \\
\hline other food crops & 0.33 & 0.33 & 0.32 & 0.17 & 0.48 & 0.66 \\
\hline $\begin{array}{l}\text { fuitts and } \\
\text { vegetablles }\end{array}$ & 3.78 & 3.78 & 5.24 & 5.63 & 6.03 & 7.65 \\
\hline oilseeds & 4.50 & 4.50 & 5.41 & 6.34 & 6.62 & 5.66 \\
\hline fibers & 0.24 & 0.24 & 0.16 & 0.07 & 0.03 & 0.01 \\
\hline fooder & 2.15 & 2.15 & 2.57 & 3.55 & 3.93 & 1.91 \\
\hline $\begin{array}{l}\text { other non food } \\
\text { crops }\end{array}$ & 0.37 & 0.37 & 0.41 & 0.42 & 0.39 & 3.06 \\
\hline \multirow[t]{2}{*}{ Total } & 100 & 100 & 100 & 100 & 100 & 100 \\
\hline & 808 & 898.8 & 973.91 & 1066.31 & 1114.99 & (1139.80) \\
\hline
\end{tabular}

Source: Statistical Abstract of Jammu and Kashmir, 2012, Department of Economic and Statistical Analysis, Government of Jammu and Kashmir. 
Fig.1.1: Changes in Cropping Pattern in Jammu and Kashmir (1965-66 to 2010-11)

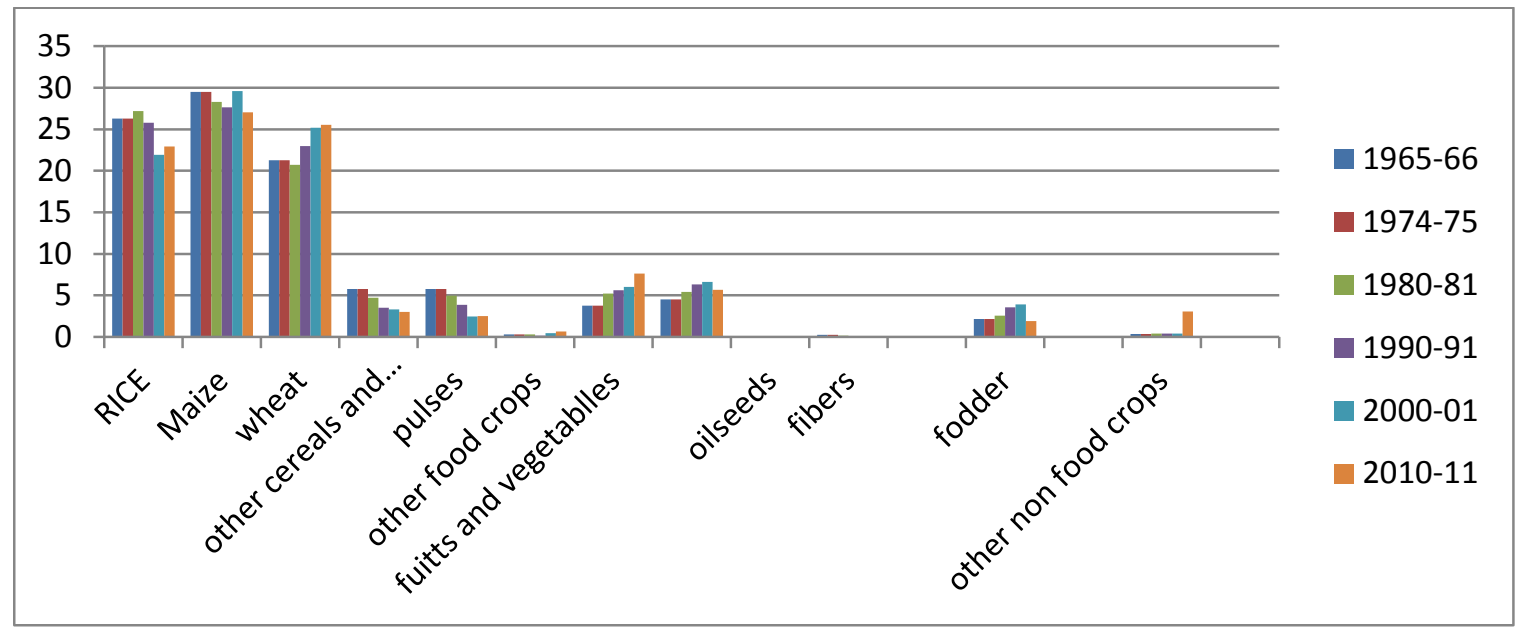

There has been also found much variation in the spatial pattern of area under various crops in the state (Table, 1.2 and Fig. 1.1). The total cropped area under maize wheat and paddy and was 308.22; 290.72 and 261.35 thousand hectare respectively during 2010-11 where it was $28.91 ; 87.19$ and 64.56 thousand hectare for pulses, fruits and vegetables and oilseeds respectively during same period in the state. The largest proportion of area under the cultivation of paddy crop has been registered in Jammu (21.1\%) followed By Kathua (12\%), Anantnag (9.37\%), Budgam (9.40\%) Kulgam (6.93\%), Baramullah (7.71), Pulwama (6.28) and Kupwara $5.81 \%$ respectively. Samba $(4.23 \%)$, Bondipora $3.79 \%)$, Ganderbal $(2.88 \%)$, Udhampur (2.83\%), Rajouri (2.09) Reasi (1.41\%) Poonch (1.40) district of the state have covered more proportional area than Srinagar (0.91\%), Doda (0.74\%), Ramband (0.52\%), Kishtwar (0.39\%), and Shopian (0.0.21\%) district under the same crop.Rajouri district has covered the largest area (15.28\%) under the cultivation of maize crop where the lowest $(0.03 \%)$ was in Srinagar district. The proportion of area under wheat crop was comparatively higher in Udhampur ( $11.34 \%)$, Doda (8.34\%), Kupwara (8.14\%), Kathua (7.92\%), Poonch (7.75), Baramullah (7.06\%), Reasi (6.44\%), Ramband (5.52), Anantnag(4.42), kishtwar (3.65), Budgam (3.22), Jammu (2.98), (1.63), Bondipora (1.58), Pulwama(1.51), Gander bal (1.48), Kulgam (1.22) Shopian (0.48) and Srinagar $(0.03 \%)$ district of the state.

Table 1.2: District-wise Cropping Pattern in Agriculture of Jammu and Kashmir, 2010-11

$\begin{array}{lllllll}\text { District } & \text { Rice } & \text { Maize } & \text { Wheat } & \text { Pulses } & \begin{array}{l}\text { Fruits } \\ \text { and Vegetables }\end{array} & \begin{array}{l}\text { Oil } \\ \text { Seeds }\end{array} \\ \text { Anantnag } & 9.37 & 4.42 & - & 4.94 & 10.03 & 25.90 \\ \text { Kulgam } & 6.93 & 1.22 & 0.001 & 2.88 & 7.39 & 8.41 \\ \text { Pulwama } & 6.28 & 1.51 & 0.11 & 1.14 & 12.08 & 21.56\end{array}$




\begin{tabular}{|c|c|c|c|c|c|c|}
\hline Shopian & 0.21 & 0.48 & 0.001 & 0.71 & 21.22 & 5.65 \\
\hline Srinagar & 0.91 & 0.03 & & 0.33 & 3.02 & 0.64 \\
\hline Ganderbal & 2.88 & 1.48 & 0.06 & 0.19 & 2.66 & 3.15 \\
\hline Budgam & 9.40 & 3.22 & 0.01 & 4.89 & 8.27 & 7.57 \\
\hline Baramullah & 7.71 & 7.06 & & 9.24 & 21.32 & 1.91 \\
\hline Bondipora & 3.79 & 1.58 & & 6.43 & 3.56 & 1.94 \\
\hline Kupwara & 5.81 & 8.15 & & 1.78 & 5.40 & \\
\hline Leh & - & & 0.89 & 0.85 & 0.49 & 0.13 \\
\hline Kargil & - & & 0.46 & 2.17 & 0.42 & \\
\hline Jammu & 21.1 & 2.98 & 30.14 & 19.33 & 1.91 & 1.89 \\
\hline Samba & 4.23 & 1.63 & 10.35 & 9.99 & 0.09 & 4.06 \\
\hline Udhampur & 2.83 & 11.34 & 11.67 & 7.28 & 0.60 & 2.58 \\
\hline Reasi & 1.41 & 6.44 & 4.20 & 1.43 & 0.02 & 0.38 \\
\hline Doda & 0.74 & 8.34 & 1.28 & 7.53 & 0.67 & 3.11 \\
\hline Kishtwar & 0.39 & 3.65 & 0.97 & 4.27 & 0.09 & 0.13 \\
\hline Ramband & 0.52 & 5.52 & 0.92 & & 0.01 & 3 \\
\hline Kathua & 12 & 7.92 & 18.77 & 13.80 & 0.42 & 5.74 \\
\hline Rajouri & 2.09 & 15.28 & 14.74 & 0.73 & 0.24 & 1.56 \\
\hline Poonch & 1.40 & 7.75 & 5.42 & 0.09 & 0.09 & 0.69 \\
\hline \multirow[t]{2}{*}{$\mathrm{J} \mathrm{k}$} & 100 & 100 & 100 & 100 & 100 & 100 \\
\hline & (261347 & (308215) & $(290722)$ & (28909) & (87190) & (64561) \\
\hline
\end{tabular}

Note: Figures in Brackets are Hectare.

Source: Statistical Abstract of jammu and kashmir, 2012, Department of Economic and Statistical Analysis, Government of jammu and kashmi 
Fig.1.2: District-wise Cropping Pattern in Agriculture of Jammu and Kashmir, 2010-11.

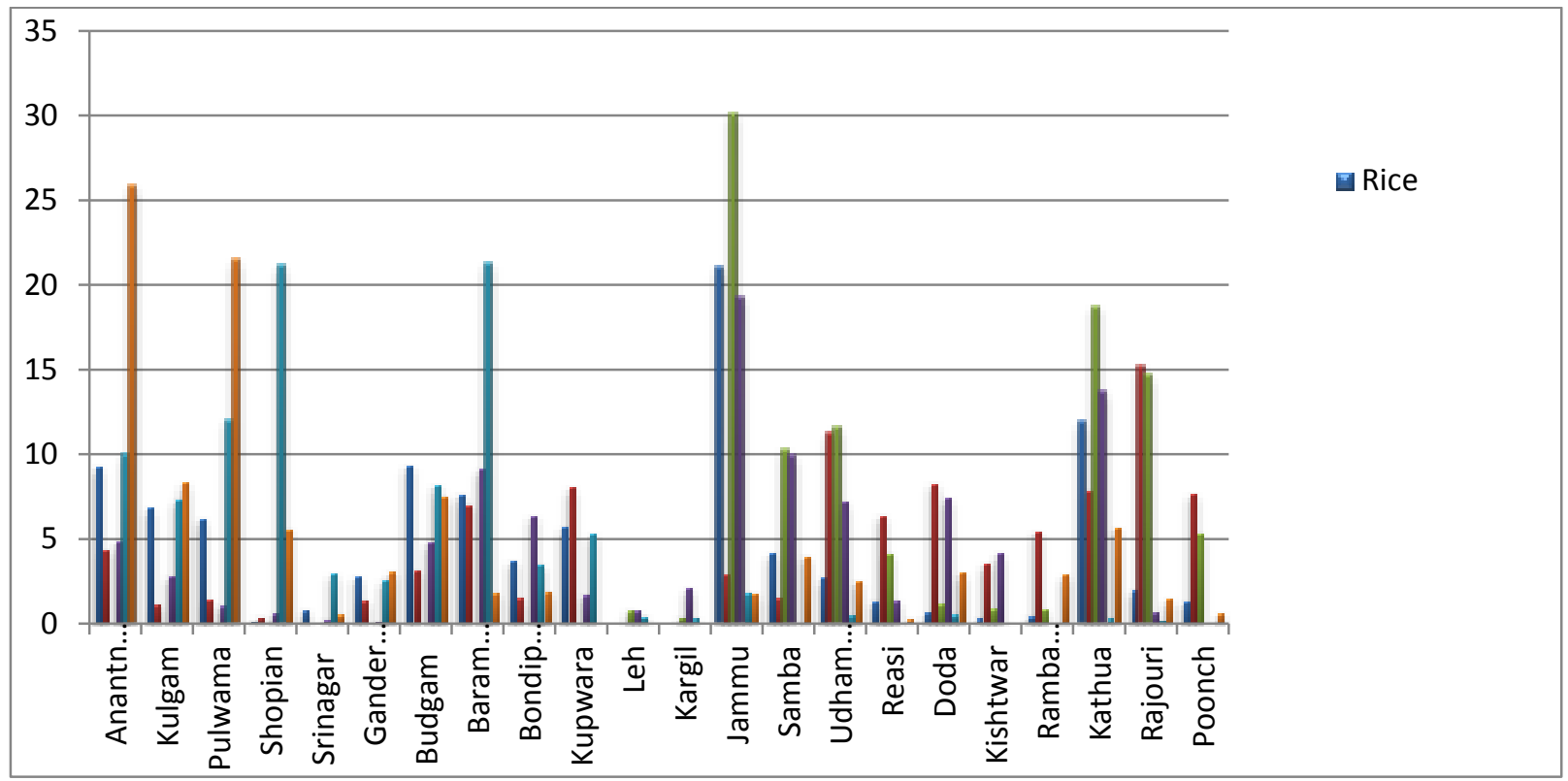

The proportion of area under cultivation of wheat crop varies between $30.14 \%$ in Jammu to $0.001 \%$ in both Kulgam and Shopian district. There has been no area found under the same crop in Anantnag, Srinagar, Baramullah, Bondipur and Kupwara district. Kathua (\%), Rajouri (10.90\%), Udhampur (7.69\%), Samba (5.47\%), Poonch (5.42) Reasi(4.20) and Doda (1.28\%) district have used more proportional area for the same crop than kishtwar (0.97\%), Ramband (0.92\%), Leh (0.89\%), Kargil (00.46\%), Pulwama (0.11\%), Ganderbal (0.06\%) and Budgam $(0.01 \%$ district.

Jammu district has captured largest proportion of area $(19.33 \%)$ for the cultivation of pulses in the state followed by Samba (9.99\%) and Baramullah (9.24\%) district respectively. Poonch district has used lowest area $(0.03 \%)$ for the same crop. Moreover, there has not been found much spatial variation in the cultivation of the same crop.Anantnag district has covered the highest proportion of area $(25.90 \%)$ under thecultivation of oilseeds whereas lowest $(0.13 \%)$ in both Leh andkishtwar districts district. Pulwama (11.85\%) Kulgam (11.12\%), Budgam (7.57\%), Shopian (5.65\%), Kathua (5.74\%), Samba (4.06\%) Ganderbal (3.15\%), Doda (3.11\%) and Ramband (3\%) district have used more area for the same crop than Udhampur (2.58), Bondipora (1.94\%), Baramullah (1.91\%), Jammu (1.89\%), Rajouri (1.56\%) Poonch (0.69\%), Srinagar $(0.64 \%)$ and Reasi $(0.38 \%)$ district. Baramullah district has used highest proportion of area under the cultivation of Fruits and vegetables with a value of $21.32 \%$ followed by Shopian (21.22\%), Pulwama (12.08\%), Budgam (8.27\%), Kulgam (7.39\%), Kupwara (5.40\%), Bondipora (3.56\%), Srinagar $(3.02 \%)$, Ganderbal $(2.66 \%)$ and Jammu $(1.91 \%)$ respectively in the state. The lowest area for the same crop has found in Doda (0.67\%), Udhampur $(0.60 \%)$, Leh $(0.49 \%)$, Rajouri (0.24\%), kishtwar (0.09\%), Poonch (0.09\%) and Reasi $(0.02 \%)$ district in the state.

Cropping Intensity has continuously increased with the augment of gross cropped areaover the period in agriculture of Jammu and Kashmir (Table, 1.3). The Cropping intensity 
was $155.78 \%$ in 2010-11 against $119.70 \%$ in 1965-66. Net sown area was 693.8 thousand hectare in 1965-66 against 731.63 thousand hectare in 2010-11.

Table 1.3: Trend of Cropping Intensity in Agriculture of Jammu and Kashmir (1965-66 to 2010-11)

$\begin{array}{llll}\text { Year } & \text { Net Sown Area } & \text { Gross Cropped Area } & \text { Cropping Intensity } \\ & \text { ('000 Hect.) } & \text { ('000 Hect.) } & \text { (Per cent) } \\ 65-66 & 675 & 808 & 119.70 \\ 74-75 & 693.8 & 898.8 & 129.54 \\ 80-81 & 715.3 & 973.91 & 136.15 \\ 90-91 & 730.71 & 1066.31 & 145.92 \\ 2000-01 & 748.31 & 114.99 & 149 \\ 2010-11 & 731.63 & 1139.81 & 155.79\end{array}$

Source: Statistical Abstract of jammu and kashmir, 2012, Department of Economic and Statistical Analysis, Government of jammu and kashmir.

There has been also found much variation in the spatial pattern of cropping Intensity in agriculture of Jammu and Kashmir (Table, 1.4 and Fig. 1.2). Samba (212.63), Jammu (212.28), Kathua (196\%), Rajouri (184.36\%), Udhampur (178.73\%), Pulwama (177.84\%) districts have high level (above175\%) of cropping intensity. Poonch(168.10\%), Reasi (153.97), Anantnag (150.92), Srinagar (144.02\%), Ganderbal (133.93\%) Ramban (133.90\%), kishtwar (130.72\%), and Kulgam (130.31\%) district have recorded moderate cropping Intensity (130-175\%). Shopian (128.84), Doda (128.27), Budgam (122.49), Bondipora (118.63\%) have registered low cropping intensity ( $130-110 \%$ ) Kargil (108.83\%), Leh (103.89\%), Baramullah (103.49\%) and Kupwara (100) have recorded very low level (below 130\%) of cropping intensity in agriculture of the state. Shopian (128.84\%), Doda(128.27\%), Budgam (122.49\%), Bondipora (118.63\%) have registered low cropping intensity ( $130-110 \%)$, Kargil (108.83\%), Leh (103.89\%), Baramullah (103.49\%) and Kupwara (100\%) have recorded very low level (below 130\%) of cropping intensity in agriculture of the state.

Table 1.4: District-wise Pattern of Cropping Intensity in Agriculture of jammu and kashmir, 2011-12 


\begin{tabular}{|c|c|c|c|}
\hline District & $\begin{array}{l}\text { Net Sown Area } \\
\text { ('000 Hect.) }\end{array}$ & $\begin{array}{l}\text { Gross Cropped Area } \\
\text { ('000 Hect.) }\end{array}$ & $\begin{array}{l}\text { Cropping Intensity } \\
(\%)\end{array}$ \\
\hline Anantnag & 47622 & 71873 & 150.92 \\
\hline Kulgam & 29019 & 37816 & 130.31 \\
\hline Pulwama & 32052 & 57004 & 177.84 \\
\hline Shopian & 19564 & 25207 & 128.84 \\
\hline Srinagar & 4570 & 6582 & 144.02 \\
\hline Ganderbal & 14438 & 19337 & 133.93 \\
\hline Budgam & 41234 & 50506 & 122.49 \\
\hline Baramullah & 64061 & 66298 & 103.49 \\
\hline Bondipur & 20817 & 24696 & 118.63 \\
\hline Kupwara & 45651 & 45651 & 100 \\
\hline Leh & 9821 & 10203 & 103.89 \\
\hline Kargil & 9873 & 10745 & 108.83 \\
\hline Jammu & 84237 & 178820 & 212.28 \\
\hline Samba & 28668 & 60957 & 212.63 \\
\hline Udhampur & 45766 & 81798 & 178.73 \\
\hline Reasi & 24567 & 37827 & 153.97 \\
\hline Doda & 30150 & 38674 & 128.27 \\
\hline Kishtwar & 16402 & 21442 & 130.72 \\
\hline Ramband & 18403 & 24645 & 133.9 \\
\hline Kathua & 63781 & 125011 & 196 \\
\hline Rajori & 53249 & 98170 & 184.36 \\
\hline Poonch & 27687 & 46544 & 168.10 \\
\hline $\begin{array}{l}\text { Jammu and } \\
\text { Kashmir }\end{array}$ & 731632 & 1139806 & 155.78 \\
\hline
\end{tabular}

Source : Statistical Abstract of Jammu and kashmir, 2012, Department of Economic and Statistical Analysis, Government of Jammu and Kashmir. 
Fig.1.3: Pattern of Cropping Intensity in Agriculture of Jammu and Kashmir , 2011-12

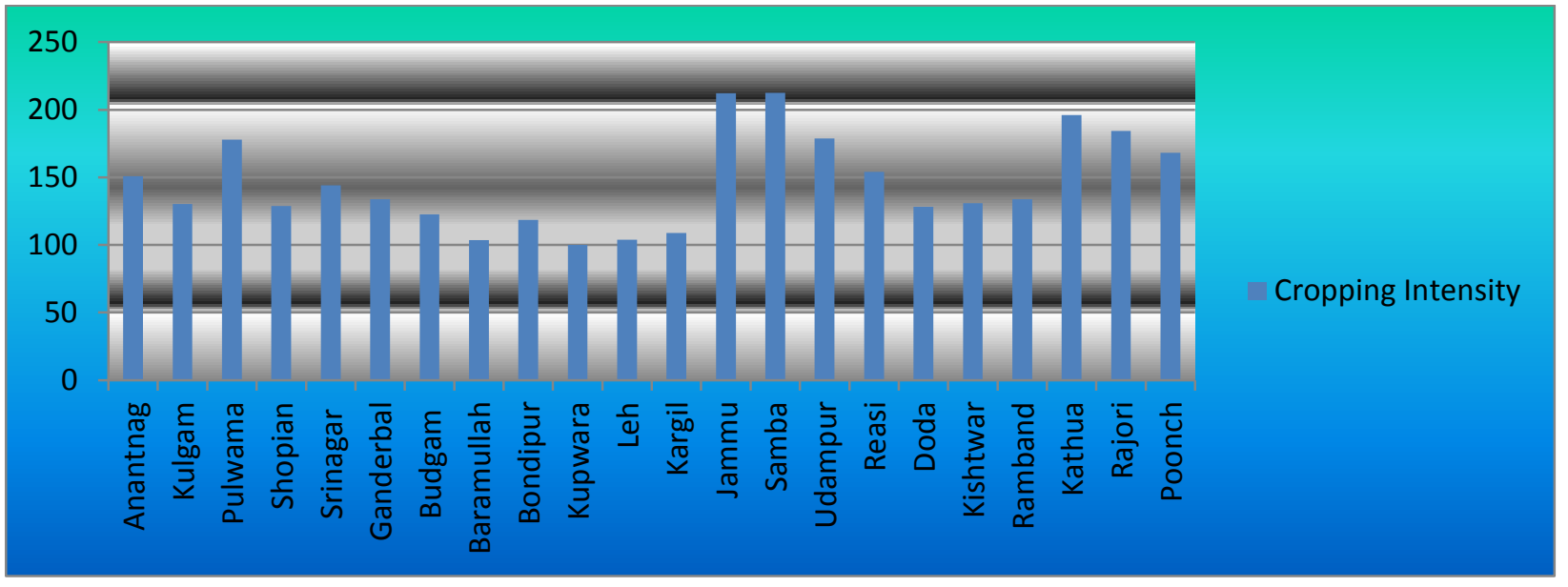

\section{Conclusion}

It can be concluded from the results of the study that Jammu and Kashmir, is more advanced in view of agricultural development with diversified cropping pattern and high level of cropping intensity. Wheat, paddy and maizehave been found as major cultivated crops in agriculture of the state which covered more than sixty per cent area of the total cropped area. Other food crops jowar and barley have been recorded as miner grown crops. There is much need to take appropriate steps for increasing the area of pulses as area under pulses has rapidly declined over the period in the state. The level of cropping intensity has reached at the saturation level in almost all districts of the state excluding Kargil, Leh, Baramullah and Kupwara district.

\section{References}

Agricultural Statistics at a Glance, 2014. Department of Agriculture and Cooperation, Directorate of Economics and Statistics, Ministry of Agricultural, Government of India.

Bhatia, S.S. (1965). "Changes in Cropping Pattern: A Study of U.P”. The Economicweekly, pp.1301-1311. Chauhan, D.S. (2010). "Agricultural Geography”. Ritu Publication, Jaipur, India.Dhindsa, K.S. and Sharma, A. (1995). "Analysis of Cropping Pattern Changes in Punjab during 1965-66 to 1990-91”. Indian Economic Review. Vol. 30(1). pp. 69-87.

Economic Survey of jammu and kashmir (2012). Department of Economic and Statistical Analysis, Government of jammu and kashmir.

Koshal, A.K. (2012). "Spatial and Temporal Cropping System Changes Over UttarPradesh-A Geographical Information System Analysis”. International Journal of RemoteSensing \& Geosciences. Vol. 1 (2). pp.1-5.

Panigrahy, S., Ray, S.S., Sood, A., Patil, L.B., Sharma, P.K. and Parihar, J.S. (2004).“Analysis of Cropping Pattern Changes in Bhatinda District, Panjab". Journal of theIndian Society of Remote Sensing, Vol. 32( 2). pp. 209-216. 